\title{
Digital collaborative consumption and social issues: The clash of taxi and Uber driver in Surabaya and Taipei
}

\author{
Konsumsi kolaboratif digital dan permasalahan sosial: \\ Benturan sopir taksi dan Uber di Surabaya dan Taipei
}

\author{
$\underline{\text { Kholifatus Saadah }}^{1}$, Shafira EInanda Yasmine $^{2}$, A. Safril Mubah ${ }^{3}$ \\ ${ }^{1,2)}$ Department of International Relations, Universitas Airlangga, Surabaya \\ ${ }^{3)}$ International Doctoral Program in Asia-Pacific Studies (IDAS), National Chengci \\ University (NCCU), Taipei \\ Jalan Dharmawangsa Dalam Selatan, Surabaya \\ E-mail: kholifatus.saadah12@gmail.com
}

\begin{abstract}
Since the occurrence of application-based taxi, phenomenon and resistance have emerged in metropolitan cities around the world. One of the main issues highlighted is digital collaborative consumption which emerges as the consequences of globalization. As an interpretive case study research, this paper aims to analyze the use of Uber as an alternative to public transportation in Taipei and Surabaya. Authors discuss the issue by comparing the reaction toward the occurrence of Uber and Taipei and Surabaya. Authors apply the theory from Hegre, Gissinger, \& Gledtisch (2002) about globalization and social conflict to explain social issues as the consequences of digital collaborative consumption as the new consumption model. According to the theory, globalization creates a deprivation which makes the struggle to access source of capital become more intense. Poverty is the main generator of radical action and violence. Analyzing the phenomena of Uber usage and the resistance from traditional taxi businessmen in Taipei and Surabaya, the authors argue that globalization reflected on digital collaborative consumption could lead to social unrest for parties who cannot adapt to the changes in economic practice. As shown by many cases of app-based rejection taxi in public places such as airport, train station and bus station; the traditionalists show resistance towards globalization and the economic shift of public transportation business model.
\end{abstract}

Key words: digital collaborative consumption; globalization, social issues, application-based taxi, social unrest

\section{Abstrak}

Sejak taksi daring mulai beroperasi, berbagai respon dan fenomena baru bermunculan di kota-kota besar dunia. Salah satu fenomena yang memantik perdebatan adalah digital collaborative consumption yang muncul sebagai dampak globalisasi. Tulisan ini merupakan hasil kajian studi kasus interpretif terhadap fenomena penggunaan Uber dan resistensi yang muncul dari pelaku bisnis transportasi konvensional di Taipei dan Surabaya. Untuk menjelaskan isu-isu sosial yang munculsebagai respon dari digital collaborative consumption, penulis menggunakan teori dari Hegre, Gissinger, \& Gleditsch (2002) mengenai globalisasi dan konflik sosial yang menyatakan bahwa adanya deprivasi material sebagai konsekuensi dari globalisasi menyebabkan usaha untuk mengakses sumber-sumber material menjadi lebih intens, dimana kemiskinan menjadi inspirasi utama dari aksi radikal dan kekerasan. Penulis menyimpulkan bahwa globalisasi yang tecermin dalam konsumsi digital di era kontemporer dapat menyebabkan permasalahan sosial bagi kelompok-kelompok yang tidak adaptatif dengan perubahan. Hal ini ditunjukkan dengan berbagai penolakan taksi daring di tempat-tempat umum seperti bandara, stasiun dan terminal sebagai bukti resistensi masyarakat lokal terhadap adanya globalisasi di dalam perubahan model bisnis angkutan umum. Proses perubahan masyarakat digital dan bisnis transportasi umum merefleksikan realitas sosial bahwa kemunculan resistensi adalah respon terhadap globalisasi dan pergeseran-pergeseran yang dibawanya.

Keywords: digital collaborative consumption; globalisasi, isu sosial, taksi daring, social unrest 
It has been said that arguing against globalization is like arguing against the laws of gravity. - Kofi Annan, $7^{\text {th }}$ Secretary-General of the United Nations

\section{Introduction}

The expansion of ride-sharing activities is challenging the long-rooted conventional public transportation system in metropolitan cities around the world. One of ride-sharing application is Uber, an application based taxi which connects drivers and passengers through smartphone application. Uber has been emerging as a manifestation of globalization in public transportation sector. For the group who has access to resources, innovation of public transportation reflected on Uber enhances possibilities and enlarges arena of activities in the transportation service (Berner \& Korff 2009:5). However, for groups who are being pushed away from the economic resource, the method shift in accessing transportation could be perceived as a threat. In the case of Uber, the new public transportation system which highly associated with the use of technology is unfavourable for conventional public transportation communities who preserve the traditional way to sell their services.

Since the beginning of 2016, issues about rejection to application-based transportation have been highlighted in various headline news in mass media in diverse regions in Indonesia. Attention was given by international media, especially after the turmoil of the clash between taxi and Uber in Jakarta, March 2016. As noted by Cochrane (2016), Indonesian capital was paralyzed by a violent mass protest by taxi and other public transportation drivers against ride-hailing applications. Protesters southing "Stop illegal taxis" or "No more apps." Demonstrators also blocked major roads and highway and attacking other taxis that did not take part in the demonstration.

The similar situation happened in Surabaya, the second largest city in Indonesia. The most recent protest was voiced by drivers of the conventional public car (angkutan umum/angkot) in front of the East Java Governor Office, in October 2017. As reported by Tribunnews.com, Bunawi, an angkot driver claimed that the emergence of online transportation had become uncontrollable. He added that government should formulate a regulation to protect the conventional public transportation existence (Tribunnews 2017). Aside from the massive protest they held in the government area, angkot drivers also conduct raids on online transportation driver who caught worked that day (regional.kompas.com 2017).

The phenomenon of the online taxi that arises in major cities in some countries raises various responses from the impacted community. Notwithstanding that parties who gladly accept this new system of transportation, there are parties who strongly reject the use of an application-based taxi. Analyzing this issue, the authors project the problem from the perspective of digital collaborative consumption by seeking the explanation of clash between Uber and taxi in current transportation system which occurred as the impact of globalization. Reflected on collaborative consumption practices in certain sectors, globalization also raises rejection from parties who felt threatened by the change which leads to protest and resistance in several major cities in the world, particularly in Surabaya and Taipei.

\section{Research Method}

This paper exposes the clash between online-based application transportation and conventional taxi using interpretive case study research method, comparing the reaction toward the occurrence of Uber in Surabaya and Taipei. The authors analyze cases in Surabaya and Taipei because of these following reasons. First, both cities are metropolitan cities in the world which enjoys technological advancement due to globalization. Both cities also faced resistance from parties who reject Uber as one of a transportation alternative. This method was chosen because it enables a new terrain to be identified by the existing theories.

The more explicit and systematic a concept, the more powerful the theory analyzes phenomena. In order to explain the effect of globalization to the transportation system in Surabaya and Taipei, authors 
applied the theory from Hegre, Gissinger, \& Gleditsch (2002) about globalization and conflict. The unit concepts used is digital collaborative consumption and social changes. The analysis explains further about the alteration of digital society in using public transportation which associated to social reality, which resistance is seen as respond of globalization and its inherent shift. Data gathered by conducting a thorough literature review related to the phenomena from existing publication in the academic journal, books, and mass media.

The motivation to choose Surabaya and Taipei as research subject was because both cities illustrated the emergence of social issues reflected on transportation system. Indeed, the massive human movement and goods are very necessary in two cities, since high mobility is mandatory to meet the needs (Joewono \& Kubota 2007). This high requirement is regarded by the company as a step to develop its products, one of them with the utilization of technology and information systems in corporate strategy.

\section{Result and Discussion}

\section{Explaining digital collaborative consumption}

In globalization studies, collaborative consumption is not a new concept. It enjoys more attention due to the massive flow of globalization, especially in the aspects of technology. Several sources mention that such consumption models have first evolved since 1950 (Felson 1978 in Tan, Tan, Choi, Lu, \& Land 2015). Bostman \& Rogers (2010) reveal the concept of collaborative consumption has the sense of economic model based on leasing, trading, and exchanging or sharing of services and products whose profits are not fully owned by actual ownership. Through this concept, the benefits of a product or service are divided into sectors which not exist in the conventional economic model. Tan et al. (2015) suggest collaborative consumption is one of sharing innovations through internet technology. In the IT-based economic practice, the use of internet technology becomes mandatory. There are some scholars who mention the advantages that encourage the high development of collaborative consumption. Tan et al. (2015) elaborates three factors which drive the development of collaborative consumption. First, the cost of procurement of products and services could be drastically reduced, thus it would be helpful for those who could not afford procurement or resources. Second, the concept is more effective and efficient in dealing with resource difficulties in the market scarcity. Third, with internet and web based activities, this economic model tends to be easier and less costly because there is no need to build or to establish too much physical procurement. As technology grows, this model also experiences a very wide development.

Nguyen (2014) argues lifestyle becomes one of factors encouraging collaborative consumption model to gain more popularity. This model is suitable with the current lifestyle. Bostman (2010) categorizes collaborative consumption models into three types. First, the mechanism of product service system. In this mechanism, manufacturers tend to offer their products in the form of services rather than selling their own products. Second, redistribution markets. This mechanism utilizes used goods, both of which have been given and no longer used or second used. This tends to save in the capital aspect because the goods used are sometimes only sold half price or even obtained for free. Third, the collaborative lifestyle. This mechanism is advantageous to connect people with the same lifestyle. Lifestyle similarity usually affects the needs and wants and formed common needs such as money, space or even skill.

Social condition has directly affected the consumption pattern in the community. This phenomenon can be explained through some previous writings. Atkinson (2012) elaborate three philosophical approaches in explaining the behavior from informants. He uses depth interview method to several samples related to their consumption patterns, namely: deontological, consequentialist and virtue ethics. Deontological and consequentialist illustrates the trend of consumption patterns are based on the responsibilities and duties of each individual, while virtue ethics emphasizes how to have good life and how to achieve it. Atkinson uses socially conscious consumption as the foundation of the third thought of the philosophy, when the pattern of consumption which is executed by individuals, not only about benefit themselves but also others. Of the samples taken, to see related articles about the details of the research process undertaken, Atkinson concludes the consumption pattern is changing 
due to the higher virtue ethics. The ethics in consuming changes the selection of used goods. They prefer to pay for higher price for opting to organic rice because of ethical reasons. This ethical reason is driven by a change in social conditions in the community, from people just fulfill their needs to be a hedonist.

Similarly, Lim Keak Cheng (1990) explains the changing pattern of consumption of Singaporean society after the many programs of the Singapore government from 1968 to 1980s. Coming the era of the 1980s when Singapore became one of the modern countries in Southeast Asia, making the pattern of consumption of Singapore people changed. Singaporean who initially prefers to consume fresh food altered their preferences to fast food.

Godwin et al (2008) believe the change in consumer patterns to consumerism is due to the large number of community groups who choose to fulfill the wants compared with the needs. This condition is mostly influenced by the changes occurring in the industrial world, from the Industrial Revolution to now. Fulfilling personal satisfaction formed in the condition of modern society, where easiness can be obtained quickly and easily. Transportation for example, quite a lot choose to use transportation technology because the selection of ease compared to using conventional transportation.

The three literatures above show that changes in society, such as lifestyle changes in Singapore that were originally another part of Malaysia and became a modern state, directly changed the consumption patterns of their communities. In line with Atkinson, modern society is more prone to ethical consumption than their needs. Likewise, the authors believe modernization has shifted consumption patterns because consumers prefer to choose the ease. However, it should be noted is the results of research conducted Atkinson also give another impact. For those who choose to adapt to change, ethical issues for example, will be more receptive to other changes in consumption patterns. This would then be in contrast to the sample from the outset who not seeing that the pattern of changes in consumption is a good thing to continue.

In the case of the new model of transportation, Uber is frequently mentioned as one business model which represents digital platform for collaborative consumption activity. Established in 2009 in San Francisco, Uber managed to record profit up to US\$1.5 billion in July 2014 (Nguyen 2014). It is a fantastic number considering Uber's relatively young age which offers a new business breakthrough. Innovation developed by Uber leads to two parties, customer and driver. Furthermore, Uber is not only targeting the city, but also large urban area where the problem of transportation is common. Compare to the fare of conventional taxi, Uber offers cheaper price. Uber also equipped with a builtin application for online transaction customers and drivers, creating more reliable transaction system for its customers.

The business system applied by Uber is in line with Lawlor's (2007) thinking, that technology is one aspect that drives globalization. Technology plays crucial role for corporations in shaping their business strategy. Utilization of technology, especially the use of smartphones, is one of the keys to the success of Uber in achieving its popularity. Through applications on smartphones, then all activities and conversations between customers and drivers can be tracked by the server so the possibility of criminality can be reduced. When entering a new city, Uber considers several factors including demand and condition of the city. Uber has a research team that will assess the readiness of a city to accept it as a public transport platform. The current internet network is also a strong reason for Uber to operate in a city due to Uber system which based on the internet network and Google maps (Nguyen 2014).

\section{Globalization and internal conflict}

Taipei is a city with a very rapid technological development, even the Sillicon Valley of Asia is attached to several points in Taipei which became the center of technology development and information systems. Seeing these facilities, obviously the providers of online taxi services tempted to have a branch in the city and get a lot of profits. However, advances in information technology and Uber's bid to go to Taipei are hampered by misunderstandings. Panji (2016) mentions a misunderstanding between Uber and the Taipei Government because initially Uber entered as a startup based on information technology, while the Taipei Government considered Uber to be a transportation service company. This misunderstanding led to the emergence of tax debt for Uber from 2013 to 2016 and 
prompted the Taipei Government to impose a ban on Uber to operate. Thus, Uber's refusal in Taipei by the local Government and taxi drivers is based on a "cultural misunderstanding" so it is seen that Uber is an illegal transport service company (Fulco 2016).

Slightly different from Surabaya, has no technological developments as well as Taipei, Surabaya also experienced rejection and ban from local Government related to operational from Uber and other online taxi. Online taxi rejection in Surabaya tends to be mostly done by conventional public transport drivers. It can be explained that the previous actor was disturbed by the arrival of new actors in the business world (Simangunsong et al. 2017). Almost the same as in Taipei, when the Government of Surabaya also saw Uber operations and others online transportation business was illegal because they do not register as transportation service provider. However, difference lies in local responds in both cities. In Taipei, the government is more aware with the development of information and technology so that companies initially based on the information system should see the context as a provider of transportation services, the Government of Surabaya did not see the condition. Rejections and restrictions are made only on the basis of the onslaught of Uber that makes conventional transport businesses suffer material losses. Therefore, it is apparent that although these two cities have differences in technological development, which is the basis of Uber, the rejection and prohibition that occurs has its own reasons based on the conditions of society and the city government itself.

The taxi industries have been operated in concrete method by ownership of physical equipment. However, the conventional way to run a business apparently has an expiration date. The world has transformed into a web which make traditional way to perform business is no longer relevant. The question is what happened to the group who could not adapt with such change. Globalization reflected in the use of transportation-based application, in fact, creates exclusion for people who refuse to be a part the transformation. This section seeks to explain the resistance of conventional taxi driver in Taipei and Surabaya.

\section{The Rejection of Uber in Surabaya}

The emergence of Uber occurred as favorable breakthrough for people who seek for easier method in using public transportation, as well as drivers looking for occupation. Globalization does make technology as an alternative in the development of business strategy. The system is breaking the traditional service provider reflected in Taxi operation system (Motala 2016). The innovation has the potential to change the nature of global public transportation system, particularly in Surabaya. Thus, this was perceived as disruption for conventional Taxi driver. Various reasons were put forward to support this rejection, from which the unhealthy competition emerged between Uber and conventional taxis up to the license of the vehicle that Uber uses (Archibugi \& Pietrobelli 2003).

Uber emerged in Surabaya in the beginning of 2016. Surabaya was selected as Uber business expansion due to the high demand of transportation alternatives. The second biggest metropolitan city in Indonesia is also undergoing development growth as the government plan to set up tram system. Uber is optimistic that its existence could supplement public transportation system which currently designed by Surabaya Government (Tempo 2016). However, Uber faced resistance from both conventional taxis and government in this city. As of 2016, Major of Surabaya, Tri Rismaharini rejected the licensing of online-based transportation such as Uber, Gojek, and Grab. Rismaharini refused to meet the Uber team because she attempted to avoid friction between online-based transportation driver and conventional taxi driver (Kompas 2016). Even though she could not deny the infiltration of technology in the current transportation system, she noticed the unjust competition between application-based driver who received subsidy from the company and conventional driver who entirely rely on their income from the road. Rismaharini also added that online taxi business should be incorporated into existing rules and legal entities (Kompas 2016). Some sources also reveal a demo between conventional taxis and some public transport drivers who feel very aggrieved with the increasing number of online taxi business.

Uber is also banned from several public places in Surabaya such as airport, bus station, and train station. Uber is allowed to take customers to those places, but prohibited to pick up customers from 
the inside. Strict rules regarding Uber operation was applied in Juanda Airport, Surabaya. Escorting passengers to leave the airport is the domain of airport taxi. If a driver gets caught picking up passengers from inside the airport, the car will be forced to stop. Passengers will be transferred to airport taxi and driver will receive penalty in various form such as warning, tires deflation, or get reported to Uber office which could cause driver's ban from Uber. Given the strict rules and supervision from airport Taxi agency, customers still prefer to choose Uber as airport transportation alternatives due to the low-price Uber applies to its customers. Riding Uber for $15 \mathrm{kms}$ from the airport approximately costs up to Rp 60-70 thousand. The same distance would cost Rp 250 thousand for airport Taxi in which the price is fixed by the driver before the ride starts.

Similar situation applied in Purbaya Bus station, Surabaya. The main entrance of the bus terminal was the base camp for conventional motorcycle (ojek) driver, offering ride for passengers to reach their destination in the city. There is a banner near the ojek base camp stated that online taxis are prohibited to take passengers from inside the bus station. If online taxis get caught taking passenger from inside the station, the vehicle's tire will be deflated. The announcement in the banner appears to be official since it attaches the logo of Indonesian police, as shown in the Figure 1.

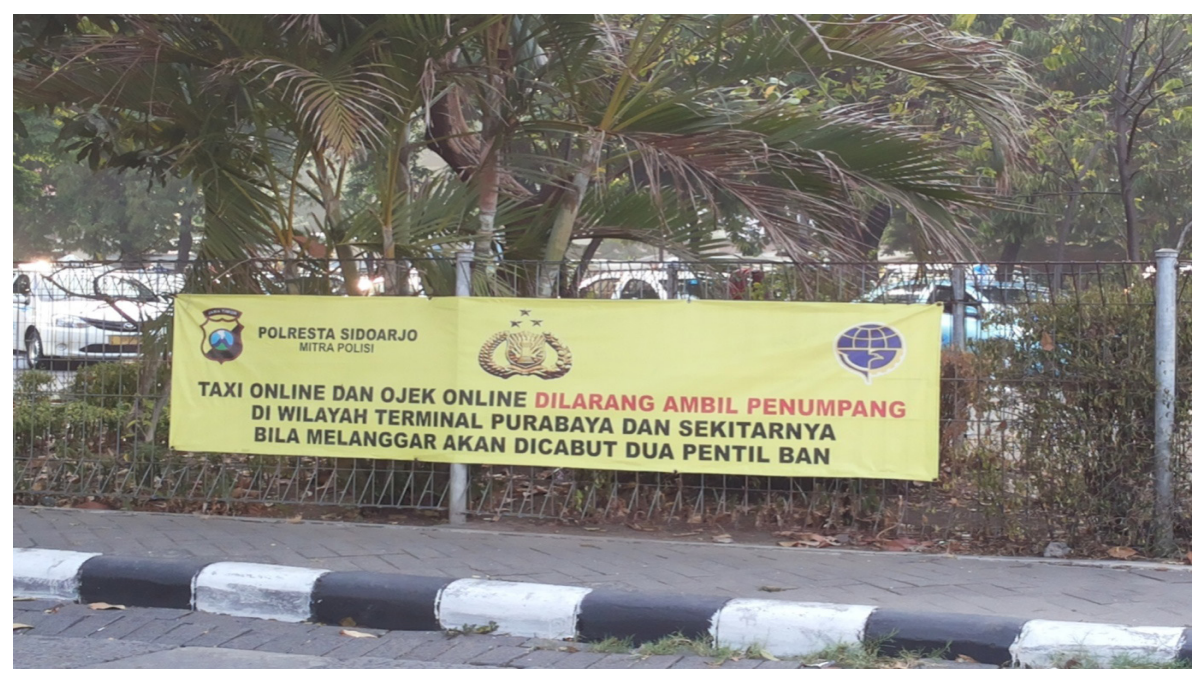

Figure 1.

Announcement of prohibition of online transportation to pick up passenger from inside the bus station area, legalized by the Ministry of Transportation and City Police Source: Personal Documentation

In the case of Purbaya Bus Station, negotiation has been made between conventional ojek, conventional taxis drivers and application-based transportation drivers. Mediated by the Waru District Police, appbased transportation drivers had agreed not to collect passengers from inside the bus station and its surrounding area (detiknews.com 2017).

\section{The Rejection of Uber in Taipei}

Taipei has a no less frightening story for Uber drivers in the Taiwan's capital. One of Uber's drivers, Lee, 28, startled to learn that the Uber driver in Taipei was required to pay a NT\$3,100 fine and lose his four-month driving license (Smith 2017). This condition was unpredictable, considering that for four-year operation in Taipei, Uber application has been downloaded by about one million people. In addition, 10,000 are registered as Uber drivers. Like in Surabaya, the Taipei government perceived that what Uber did was too aggressive to the detriment of other conventional public transport. The fine policy for Uber drivers in Taipei has actually started to emerge since 2016. Ho (2016) revealed that in 2016 the police in Taipei applied inspection for the use of private vehicles as Uber. The penalty amounted to NT\$ 1,534 on the first warning by disabling the license for two months. If the driver caught inspection again, the fine would be NT\$2,454 and 6-month prohibition of driving. Finally, if a driver recorded to violate the law up to five times, the driving license would be disabled. 
Uber's problems in Taipei drew from Taiwan's own government and protests from conventional taxi drivers. In July 2014, around 1,200 taxi drivers seized the streets, caused severe jam on Renai Road (Horwitz 2014). The protest was addressed to the Ministry of Technology and Communication, related to the widespread use of Uber in Taipei. The protest was not only about the unfair competition, but Uber was seen as illegal transportation. Furthermore, it was added to government rules imposing fines and bans on Uber for standard and tax reasons. In response to the controversy over the ban and imposition of fines to all Uber users, especially to drivers, Audrey Tang, representative of Taiwan's digital minister, conducted a meeting with Uber in August 2016.

The meeting led to the decision that Uber as a company will attempt to improve the quality of the driver. The driver problems had often been used as an instrument to suppress Uber performance. A lot of people stated that nonstandard cars as well as driver capabilities are becoming one of the reasons for the rejection of Uber operations in Taiwan, especially in Taipei itself where Uber operates (Tang 2016). Another problem is the rejection of the conventional taxi almost in every Uber operation area. The rejection is not as violent as what happened in Surabaya. But the Taipei Taxi Driver Association considers Uber as an unfair rival. It was because the reasons from customers in Taipei (and Taiwan in general) are less expensive than other public transport. Pol.is, one of the media that provides online polls and accessible to anyone is used by Tang (2016) to see the response of Taiwanese society related to Uber operation. The result is quite surprising when $77 \%$ reveal that they prefer to find Uber despite the many taxis on the highway.

The government's argument to impose a temporary ban on Uber, appears on administrative matters. Uber as a retail company does not make tax payments which is high enough, to the government and is deemed not to provide a standard to the used car (Shu 2017). This is the concern of the company which they are keen to improve their performance. This was proven that in April-May 2017, Uber seeks to hold an official car rental service to provide the vehicle on behalf of Uber, as expressed directly by Uber's Taiwan branch manager, Likai Gu (Shu 2017). However, the tax problem still has not found a solution between them. The government warned Uber that if they remain not building a mechanism to pay taxes, operational permits of Uber in Taipei and Taiwan can be revoked and the drivers will be fined in a considerable amount of money and lead to the revocation of driver's license.

\section{Those who are excluded from Uber civilization: (In)adaptability}

Globalization forces are a double-edged sword. While globalization tends to increase social and economic welfare, it also causes disruption in traditional commercial sectors (Motala 2017:472). In the use of Uber, GPS-enabled location-based applications are challenging traditional method of social interaction and commercial power in contemporary legal, political and economic life. The sharing economy creates a common digital platform that allow all participants to buy goods and services directly from the supplier. Such innovation has the potential to alter the nature of global commerce. Globalization is no longer reflected in the activities of large multinational corporations. In fact, small and medium-sized enterprises eventually achieve the level where their activity heavily relies on technology. The inclusive nature of globalization allows individual to discover opportunities, information and ideas from all over the world (McKinsey Global Institute 2016:43).

In many metropolitan cities on the globe, transportation has become the most vulnerable aspect to the impact of sharing economy system (Motala 2016:468). Since the mushrooming of applicationbased taxi, the income of taxi driver has fallen approximately to $60 \%$ compared to their previous income. Their daily income used to amount to Rp 300 thousand is decreasing to Rp 100 thousand. Taxi drivers claimed that the competition has severely reduced their income because Uber and Grab did not meet government's requirement to operate transportation business. Taxi drivers consider their competition as 'illegal taxis', since Uber are offering rides at lower prices and assumed that they are not paying taxes and operating without official permits (Al-Jazeera 2016). The phenomenon projects a situation where taxi drivers are exposed to human insecurity as the consequence of globalization.

Analyzing this issue from the perspective of digital collaborative consumption and globalization, Kasali (2016) suggest the concept of 'sharing economy'. The shift of economy model has led to friction between the parties who choose to 'adapt' and those who preserve the old rules about how to run business. Before digitalization era, in order to run a business, people should possess concrete 
materials as business asset. This business model leads to the need of massive amount of capital to run a business. In digital era, this method is no longer efficient due to simplicity of asset sharing gauged by new actors of business under the stream of globalization (Kasali 2016). The emergence of new technology requires a new mindset, and this mindset is well-grasped by businesspeople who choose digitalization to support a business.

For taxi companies' management, the new business model run by Uber and another applicationbased transportation is not easy to understand (Kasali 2016). Encountering Uber with substantially lower cost, the conventional taxi has become reactive in responding the issue. Online transportation claims themselves not as a transportation company but as an application corporation (Kasali 2016, 76). Applying application based business model, Uber does not require capital expenditure as much as conventional taxi need since their vehicles are possession of Uber's partners. Without having to obey the regulation in taxi industries, application-based transportation could gain benefit from linking consumers with Uber's network (Kasali 2016:76).

Policy makers of the old transportation business model have bounded with great amount of fixed cost. The price offered by taxi is unfavorable for consumers. On the other hand, consumers are the main keys of Uber's sustainability. Consumers has right to directly assess Uber's performance by giving review for driver and its services. In other words, digitalization brought by Uber system provides more space to consumers to be a part of the company's betterment. Sudden migration of consumers from taxi to Uber constructs a perspective of taxi driver that Uber occurrence in Indonesia was a threat, appear in a form of an unfair competition.

As digital collaborative consumption through Uber enjoys more popularity in Indonesia, the country faced with two options. First, avoiding the stream and preserving 'owning economy', which risking the digital market to operate illegally with operator from outside the nation's boundaries, or, legalize sharing economy and encourage the traditionalists to adapt with the change (Kasali 2016).

\section{Is resisting globalization possible?}

In the case of Uber, globalization encompasses social dimensions such as security, cultural identity, social welfare, individual identity, and social cohesiveness. The gap created in by the use diminishing use of conventional taxi as public transportation alternative indicates the emergence of economic liberalization as the consequences of globalization (Westaway 2012:133). It is emphasized that the existing political and social institutions were inadequately prepared to deal with the social relations accompanying globalization.

All levels of society are reshaped by globalization, as argued by Ebaye (2012):

"the individual livelihood is threatened or identity thrown into question, localities are forced to recreate themselves or die in the face of economic forces, and nations are experiencing steadily decreasing freedom of action. The contemporary form of globalization, driven by economic power clearly promotes the hegemony of Western culture and corporations, puts jobs and communities at risks,"

The Friedman's work (2005) is possibly the most impactful thought of globalization in the first decade of the $21^{\text {st }}$ century. However, as the world is rapidly changing, more elements of daily life are becoming more involved in the stream of globalization, compare to Friedman's prediction 12 years ago. The difference between 'old' globalization and the 'new' globalization is shown in the Table 1. 
Table 2.

Globalization in the $20^{\text {th }}$ century and the $21^{\text {st }}$ century

\begin{tabular}{|c|c|}
\hline $20^{\text {th }}$ century & $21^{\text {st }}$ century \\
\hline tangible flows of physical goods & Intangible flows of data and information \\
\hline flows mainly between advanced economies & greater participation by emerging economies \\
\hline capital and labor intensive flows & more knowledge intensive flows \\
\hline transportation infrastructure is critical for flows & digital infrastructure becomes equally important \\
\hline multinational companies drive flows & growing role of small enterprises and individuals \\
\hline flows mainly of monetized transactions & more exchange of free content and services \\
\hline Ideas diffuse slowly across borders & instant global access to information \\
\hline $\begin{array}{c}\text { Innovation flows from advanced to emerging } \\
\text { economies }\end{array}$ & innovation flows in both direction \\
\hline
\end{tabular}

Given the fact from the Table 1, it is clear that globalization is present in almost every aspect of livelihood. Globalization provides more space for individual participation from various backgrounds. Whether society embraces it or not, we are entering a new social order called digital society (Permadi 2016). Digital platforms are the key to the new era of globalization. Through digital platforms, corporations built their own platforms to manage suppliers, connect to customers, and enable internal communication. The diverse set of public internet platforms has connected anyone from any places (McKinsey Global Institute 2016). Globalization that was once driven almost exclusively by government, large multinational corporations, and major financial institutions are shifting. Today, entrepreneurs, application developers, freelancer, even individual can participate directly on digital platform. Individual are forming their own connections, as business and economic implications of individual participation goes more significant.

In Indonesia, President Joko Widodo has welcomed the competition of conventional taxi and application-based taxi (Al Jazeera 2016). The Indonesian Minister of Communication and Information, Rudiantara, refuses to ban ride-hailing application as they are part of Indonesia's growing digital economy (Cochrane 2016). The new form of interaction reflected on digital lifestyle is indicated by the growing of digital literacy and the spread of people who use internet. In the case of Uber penetration in Indonesia, digitalization provides complete information about various choices in people's mobility. The more information about available options, the less people feel uncertain in making decision. Certainty helps people to choose most beneficial choice. This premise is not only applied in transportation system, but also applied in other sectors such as money, energy, and time (Permadi 2016).

Therefore, the dilemma of the widening gap between those who were favored by globalization and those who are not should be reduced by applying most suitable policy. Prohibiting the new business models only restrain innovation and limit the possible benefits from the new model (Hutaurauk, 2016). Since the main complaints from taxi drivers are about Uber legality due to Uber's flexibility in paying taxes, government should create a new regulation that requires Uber car owner to register through a limited liability company (LLC). Learning from other countries, Uber requires driver to submit their tax identification number when they register with Uber. This approach will reduce the risk of tax-loses revenue of government. Some countries have already required Uber drivers to register at their taxation office. From August 2015, the Australian Taxation Office (ATO) confirmed all Uber drivers have to register for the goods and services tax (GST) and submit the GST portion 
of their Uber fares to the ATO (Hutauruk 2016). Most importantly, there is an urgent need of deeper assessment about the phenomena of application-based transportation usage. By conducting a deeper assessment, government can implement the right policy response on a suitable timing.

\section{Conclusion}

The phenomenon of online taxi that arises in major cities in some countries raises public responses in responding to the issue of this online taxi. In Taipei, the government made an arrangement and issued government regulation in approaching the problem. In Surabaya, the government refused to hold a meeting with Uber team, stating that the competition is unjust for conventional taxi and angkot drivers. There is only prohibition with no legal regulation attached in solving the resistance from conventional taxi, angkot, and ojek drivers. Thus, they tend to act independently to judge and to capture Uber's driver who got caught picking up passengers in their claimed area. Due to differences in public transportation system in two cities, local people respond the issues differently. In Surabaya, the social unrest is more severe due to inequality between existing public transportation and application-based transportation. In Taipei, the occurrence of Uber is not really affecting the community because the system of public transportation in Taipei is convenient.

Different responses in society occurred in responding the disruption. Some strongly rejected the innovation while there are parties who accept the digitalization in the transportation business. The authors argue that social unrest and violence performed by taxi driver is regarded as an act of inadaptability toward the new model of public transportation business. The phenomenon projects a situation where taxi drivers are exposed to marginalization and exclusion as the consequence of globalization. However, modern society should realize that globalization cannot be reversed nor avoided. It is not an option to join or to dissociate with the stream. The emergence of new technology requires a new mindset, and this mindset is well-grasped by business people who choose digitalization to support a business. What society needs the most is a narrow gap between the actors of the new business model and the alienated group as the key to tame the social unrest.

\section{References}

Al-Jazeera (2016) Indonesia's Jakarta Shut Down by Taxi-driver Protest, 22 March 2016.

Archibugi D \& Pietrobelli C (2002) The globalization of technology and its implications for developing countries, windows of opportunity or further burden? Elsevier Science Inc. Juni-Desember: 861-883.

Atkinson L (2012) Buying in to social change: How private consumption choices engender concern for the collective. The ANNALS of the American Academy of Political and Social Science, 644 (1):191-206.

Berner E \& Korff R (2009) Globalization and local resistance: The creation of localities in Manila and Bangkok. International Journal of Urban and Regional Research 19 (2):208-222.

Botsman R (2010) Beyond zipcar: Collaborative consumption (Idea Watch). Harvard Business Review, 88 (10).

Cheng LK (1990) Social change and fresh-food marketing in Singapore. GeoJournal 20: 301. https:// doi.org/10.1007/BF00642995.

Cochrane J (2016) Protest in Indonesia against ride-hailing apps turns violent. The New York Times, 22 March.

Demo, Sopir Angkot Sempat "Sweeping" Angkutan Online di Surabaya (2017) [Accessed 23 October 2017]. http://regional.kompas.com/read/2017/10/03/16125251/demo-sopirangkot-sempat-sweeping-angkutan-online-di-surabaya.

Ebaye SE (2012) The inter connectedness of globalization and social conflict in Africa. Basic Research Journal of Social and Political Sciences, 1 (3).

Fulco M (2016) Taiwan's Continuing Uber Controversy. [Accessed 22 April 2017]. https://topics. amcham.com.tw/2016/12/continuing-uber-controversy/.

Fulco M (2016) Taiwan's continuing Uber controversy. [Accessed 28 December 2017]. https://topics. 
amcham.com.tw/2016/12/continuing-uber-controversy/.

Hegre H, Gissinger R \& Gleditsch NP (2002) Globalization and internal conflict. Coulder, CO: Roman \& Littlefield.

Ho V (2016) It'll be harder to grab Uber in Taipei as harsher crackdown begin. [Accessed 22 April 2017]. http://mashable.com/2016/05/31/uber-taipei/\#MmldpBv6Wkq1.

Horwitz J (2014) Uber hits first backlash from taxis in Asia as Taipei cabbies block streets in protest. [Accessed 12 September 2017]. https://www.techinasia.com/taipei-taxi-industry-driversprotest-uber-backlash-in-asia

Joewono TB \& Kubota H (2007). User perception of private paratransit operation in Indonesia. Journal of Public Transportation 10 (4):99-118.

Kasali R (2016) [acessed 22 April 2017]. Sopir taksi dan fenomena 'Sharing Economy'. http:// bisniskeuangan.kompas.com/read/2016/03/22/054000126/Demo.Sopir.Taksi.dan. Fenomena.Sharing.Economy.?page=all,.

Kasali R (2017) Disruption. Jakarta: Gramedia.

Kompas (2016) Surabaya Tolak Izin Angkutan Umum Online: Ini Alasan Risma. [Accessed 22 April 2017]. http://regional.kompas.com/read/2016/03/28/07083301/Surabaya.Tolak.Izin. Angkutan.Umum.Online.Ini.Alasan.Risma.

Lawlor BR (2007) The age of globalization: Impact of information technology on global business strategy, Senior Capstone Project, April.

Massa demo angkot tuntut ditemui Guernur Soekarwo (2017) [Accessed 23 October 2017]. http:// www.tribunnews.com/ regional/2017/10/03/massa-demo-angkot-tuntut-ditemui-gubernursoekarwo.

McKinsey Global Institute (2016) Digital Globalization: The New Era of Global Flows, McKinsey\&Company.

Nguyen GT (2014) Exploring collaborative consumption business models case peer-to-peer digital platforms. Organization and Management Master's thesis Department of Information and Service Economy Aalto University School of Business.

Oludimu O (2014) Globalization, human security and some intervening concerns, European Scientific Journal, Special Edition.

Panji A (2016) Uber Diminta Bayar Pajak di Taiwan. [Accessed 28 December 2017]. https://www. cnnindonesia.com/teknologi/20160822111248-185-152931/uber-diminta-bayar-pajak-ditaiwan/.

Permadi D (2016) [accessed 13 April 2017] Prof. Rhenald Kasali, Istilah 'Sharing Economy' sepertinya kurang pas! http://www.kompasiana.com/dpdedypermadi/profrhenaldkasaliistilahsharingeconomysepertinyakurangpas_56f288cbf29273150a251035.

Rashbrooke M (2017) How Taiwan is inoculating itself against the Uber "virus". [Accessed 12 September 2017]. http://www.citymetric.com/business/how-taiwan-inoculating-itselfagainst-uber-virus-2786.

Shu C (2017) Uber returns to Taiwan after partnering with licensed rental car companies. [Accessed 12 September 2017]. https://techcrunch.com/2017/04/13/uber-taiwan-return/.

Simangunsong JT, Aprianingsih A, Madgalena I (2017) Understanding the rejection phenomena of technology based transportation new entrant. Journal of Engineering and Applied Sciences 12 (17):4367-4373.

Smith N (2017) Want to make some money in Taiwan? Report your Uber Driver to the Police. [Accessed 22 April 2017]. http://time.com/4632430/taiwan-uber-fines/.

Sprinz DF \& Wolinsky Y (eds) (2004) Case, numbers, models: International relations research methods. Ann Arbor: University of Michigan Press.

Tan A (2016) Uber responds to Taiwan's coherent blended volition. [Accessed 12 September 2017]. https://blog.pol.is/uber-responds-to-vtaiwans-coherent-blended-volition-3e9b75102b9b

Tan FTC, Tan B, Choi BCF, Lu A \& Land LPW (2015) "Collaborative Consumption On Mobile Applications: A Study Of Multi-sided Digital Platform GoCatch" 2015 International Conference on Mobile Business. 11. https://aisel.aisnet.org/icmb2015/11. 